\title{
Penyusunan Masterplan Kampung Purbonegaran Berbasis Potensi Lokal untuk Pengembangan Perekonomian Warga
}

\author{
Patricia Pahlevi Noviandri ${ }^{\# 1}$, Wiyatiningsih ${ }^{* 2}$, Christian Nindyaputra Octarino ${ }^{\# 3}$ \\ ${ }^{\#}$ Prodi Arsitektur, Fakultas Arsitektur dan Desain, Universitas Kristen Duta Wacana \\ Jl. Dr. Wahidin Sudirohusodo 5-25, Yogyakarta \\ 1patriciapahlevi@staff.ukdw.ac.id \\ ${ }^{3}$ christian.octarino@staff.ukdw.ac.id \\ *2. Lembaga Penelitian dan Pengabdian kepada Masyarakat, Universitas Kristen Duta Wacana \\ Jl. Dr. Wahidin Sudirohusodo 5-25, Yogyakarta \\ ${ }^{2}$ wiyatiningsih@staff.ukdw.ac.id
}

\begin{abstract}
Abstrak-Keterbatasan lahan Kota Yogyakarta seringkali menjadi kendala dalam penataan dan pemanfaatan ruang kota. Untuk itu diperlukan perencanaan ruang yang lebih komprehensif dengan melibatkan seluruh pemangku kepentingan. Mempertimbangkan hal tersebut, pemerintah Kota Yogyakarta mengembangkan program Gandeng Gendong sebagai sarana kolaborasi lima unsur (5K - kota, korporasi, kampus, kampung, dan komunitas). Sebagai bagian dari unsur 5K, tim PkM UKDW terlibat dalam implementasi program Gandeng Gendong melalui kegiatan penyusunan masterplan Kampung Purbonegaran di Kelurahan Terban. Penyusunan masterplan ini dilakukan dengan metode perancangan partisipatif yang melibatkan warga melalui wawancara dan focus group discussion. Data diperoleh melalui observasi dan wawancara yang diawali dengan identifikasi potensi lokal Kampung Purbonegaran sebagai kampung budaya, sayur, dan herbal. Kegiatan ini dilakukan selama 2 tahun (2020-2021) dengan mitra adalah Kampung Purbonegaran pada tahun pertama dan selanjutnya dengan Kelompok Kerja Kampung Keluarga Berkualitas (KB) Purbonegaran yang bertugas untuk mengembangkan kesejahteraan dalam bidang sosial dan ekonomi. Masterplan ini disusun dengan strategi pemetaan potensi, permasalahan, kekuatan, dan kelemahan dari Kampung Purbonegaran. Dengan demikian, masterplan yang dihasilkan diharapkan dapat tepat sasaran. Hasil dari kegiatan PkM ini berupa masterplan yang berisi program-program pembangunan sarana dan prasarana yang diprediksikan akan berdampak bagi kehidupan warga, antara lain Lorong Strawberry, Belik Kids Sanggar Belajar, Taman Ekologi, Lorong Bambu dan meeting point, serta kios portable yang digunakan untuk kewirausahaan Kampung KB Purbonegaran.
\end{abstract}

Kata kunci-Gandeng Gendong, Kampung Purbonegaran, masterplan, perancangan partisipatif, kewirausahaan
Abstract-The limited land in the city of Yogyakarta is often an obstacle in the arrangement and utilization of urban space. This requires a more comprehensive spatial planning involving all stakeholders. Considering this, the Yogyakarta City government developed the Gandeng Gendong program as a means of collaboration with five elements (city, corporation, campus, village, and community). As part of the $5 K$ element, the UKDW Community Service team was involved in implementing the Gandeng Gendong program through the preparation of the Purbonegaran Kampong master plan in Terban Village. The preparation of this master plan was carried out using a participatory design method that involved residents through interviews and focus group discussions. Data were obtained through observation and interviews, which began with the identification of the local potential of Kampong Purbonegaran as a village of culture, v@egetables, and herbs. This activity was carried out for 2 years (2020-2021) with partners namely Purbonegaran Kampong in the first year and thereafter with the Purbonegaran Keluarga Berkualitas (KB) Working Group whose task was to develop welfare in the social and economic fields. This master plan was prepared with a strategy of mapping the potential, problems, strengths, and weaknesses of Purbonegaran Kampong. Thus, the resulting master plan is expected to be right on target. The results of this community service activity are in the form of a master plan containing facilities and infrastructure development programs that are predicted to have an impact on people's lives, including Strawberry Lorong, Belik Kids Learning Studio, Ecology Park, Bamboo Lorong and meeting points, as well as portable kiosks used for entrepreneurship of Keluarga Berkualitas (KB) Purbonegaran.

Keywords-gandeng gendong, kampong purbonegaran, masterplan, participatory design, entrepreneurship 


\section{Pendahuluan}

Kota merupakan sebuah ekologi dari berbagai makhluk hidup yang melakukan aktivitas [1]. Kota memiliki permasalahan yang kompleks dan tidak dapat diselesaikan hanya pada satu layer saja. Permasalahan tersebut beranjak pada permasalahan sosial yang menimbulkan permasalahan ekonomi, yang selanjutnya berdampak pada masalah lingkungan. Perencanaan kota yang menggunakan pendekatan Sustainable Development memiliki peluang keberhasilan yang tinggi. Hal tersebut disebabkan bahwa pendekatan tersebut merupakan sebuah perencanaan pembangunan yang memikirkan 3 aspek penting yaitu ekonomi, sosial, dan lingkungan. Permasalahan sosial yang terlihat pada masyarakat Indonesia yaitu mengenai kesejahteraan masyarakat berupa kemiskinan dan ketidakmerataan [2] pembangunan sosial dan fisik. Permasalahan tersebut menjadi sangat penting dan mendasari permasalahan-permasalahan kota yang lain.

Program-program yang sudah dilakukan pemerintah dalam mengatasi permasalahan sosial perlu dilakukan evaluasi secara berkala. Banyak program pemerintah beberapa tahun yang lalu hanya menitikberatkan pada usaha pemerintah dan bersifat Top-Bottom. Kota Yogyakarta yang memiliki permasalahan kemiskinan dan ketimpangan pendapatan, menginisiasi program Gandeng Gendong. Menurut Wakil Walikota Yogyakarta pada tahun 2020 Heroe Poerwadi, Program ini digunakan untuk pemberdayaan dan peningkatan ekonomi masyarakat, khususnya percepatan penanggulangan kemiskinan dengan lebih menekankan pada pemberdayaan masyarakat [3]. Program Gandeng Gendong yang dProgram Gandeng Gendong Kerjasama lima elemen yaitu pemerintah kota, korporasi, kampus, kampung dan komunitas yang saling membantu dalam menurunkan angka kemiskinan di Kota Yogyakarta [4]. Implementasi program Gandeng Gendong ini efektif yang terlihat dari meningkatnya pemukiman kumuh menjadi pemukiman yang bersih, sehat, dan produktif. Selain itu muncul dan kuatnya Usaha Mikro, Kecil, dan Menengah (UMKM) di Kota Yogyakarta.

Sinergitas antara lima elemen menjadi kekuatan untuk pembangunan bidang ekonomi, sosial, budaya, dan lingkungan. Pembangunan di segala bidang dibutuhkan perencanaan yang komprehensif. Perencanaan wilayah dibutuhkan karena beberapa hal antara lain [5]:

1. Potensi wilayah

2. Kemampuan teknologi dan perubahan yang cepat dalam kehidupan manusia

3. Kesalahan perencanaan yang sudah dieksekusi di lapangan sulit diubah

4. Ketersediaan lahan
5. Tatanan wilayah

Saat ini, kebutuhan dokumen perencanaan wilayah yang perlu dimiliki sampai ditingkat Kampung berupa masterplan. Masterplan adalah perencanaan yang berdasarkan analisis wilayah kajian yang dapat memberikan suatu design guidelines. Tahun 2021, Kota Yogyakarta memasuki fase ketiga dalam implementasi Program Gandeng Gendong dengan melakukan penyusunan masterplan pada 42 Kelurahan [6]. Penyusunan masterplan ini diharapkan menjadi kegiatan integrasi antar program, sumber daya manusia, dan anggaran dari pihak-pihak yang terlibat. Penyusunan masterplan menjadi salah satu usaha peningkatan kesejahteraan masyarakan yang terencana.

Pandemi COVID-19 yang telah berlangsung selama hamper 2 tahun ini, berdampak besar terhadap semua aspek kehidupan, termasuk ekonomi. Beragam bisnis berbasis online bermunculan seiring dengan protokol kesehatan COVID-19 menurut WHO dan pemerintah yang mengharuskan orang untuk menjaga jarak atau social distancing, yang kemudian diubah menjadi physical distancing. Salah satu cara yang digunakan oleh WHO untuk mencegah penyebaran virus corona adalah dengan menetapkan social distancing, yaitu tindakan yang tidak memperkenankan orang untuk berjabat tangan dan menjaga jarak setidaknya satu meter saat berinteraksi dengan orang lain [7].

Salah satu bisnis online yang berkembang pada masa pandemi COVID-19 adalah bisnis kuliner dengan beraneka jenis olahan makanan. Perkembangan bisnis kuliner pada masa awal pandemi COVID-19 tahun 2020 ini bisa dipahami karena kebutuhan orang untuk mendapatkan makanan tanpa harus keluar rumah karena instruksi "stay at home", di satu sisi. Di sisi lainnya, banyaknya orang yang harus bekerja di rumah atau bahkan dirumahkan dari pekerjaannya, mendorong orang untuk mencari sumber penghasilan baru yang dapat mengganti sumber penghasilan sebelumnya. Fenomena bisnis kuliner online ini terjadi juga pada masyarakat Kampung Purbonegaran di Kelurahan Terban, Kota Yogyakarta.

Pada tahun 2021 ini pandemi belum berakhir, namun aktivitas masyarakat sudah berjalan kembali. Roda perekonomian harus terus berputar supaya dapat mempertahankan kehidupan, demikian pula halnya yang terjadi dengan masyarakat Kampung Purbonegaran. Melalui kelompok Kampung KB (Keluarga Berkualitas) Purbonegaran, warga Kampung Purbonegaran didukung untuk mengembangkan usaha kuliner, khususnya yang berupa jajan pasar, melalui warung pagi yang dikelola oleh pengurus Kampung KB Seksi Ekonomi.

Kampung KB Purbonegaran dibentuk oleh Camat Gondokusuman, Kota Yogyakarta berdasarkan Keputusan Camat No. KEP.GK/XI/2019 tentang pembentukan 
Kelompok Kerja (Pokja) Kampung Keluarga Berencana (Kampung KB) Kampung Purbonegaran. Kampung KB pertama kali dicanangan oleh Presiden RI pada bulan Januari 2016. Kampung KB adalah satuan wilayah setingkat desa dengan kriteria tertentu dimana terdapat keterpaduan program Kependudukan, KB dan Pembangunan Keluarga (KKB-PK) dan pembangunan sector terkait dalam upaya peningkatan kualitas hidup keluarga dan masyarakat [8]. Tujuan dari pembentukan Kampung KB yaitu untuk meningkatkan kualitas hidup keluarga dan masyarakat. Kampung KB dibentuk atas dasar untuk meningkatan peran serta pemerintah, Lembaga non pemerintah dan swasta dalam menfasilitasi, mendampingi dan membina masyarakat untuk menyelenggarakan program KKBPK dan pembangunan sector yang terkait. Selain itu kampung KB dibentuk untuk meningkatkan kesadaran masyarakat tentang pembangunan berwawasan kependudukan. Kampung KB merupakan wahana pemberdayaan masyarakat yang bekerjasama dengan mitra-mitra lintas sector yang dilakukan secara sistemik dan sistematis.

Strategi dalam pencapaian tujuan dari Kampung KB yaitu mendekatkan pelayanan KKB-PK, Penguatan 8 fungsi keluarga, partisipasi aktif masyarakat, pembangunan terintegrasi lintas sector. Delapan fungsi keluarga yang dimaksud antara lain: fungsi agama, fungsi social budaya, fungsi cinta kasih, fungsi perlindungan, fungsi reproduksi, fungsi sosialisasi Pendidikan, fungsi ekonomi, dan fungsi lingkungan. Tujuan adanya keluaga ini diharapkan keluarga Indonesia dapat menjadi keluarga yang sejahtera dan berkualitas.

Visi kelurahan terban adalah sebagai Kelurahan Budaya [9]. Visi tersebut diturunkan pada Kampung Purbonegaran yang menjadi Kampung Budaya, Sayur dan Herbal. Setelah melakukan identifikasi potensi di Kampung Purbonegaran, ditemukan bahwa Kampung Purbonegaran memiliki potensi ekonomi pada bidang kuliner. Kuliner yang dilakukan berbasis keluarga berupa jajan pasar, snack, perikanan lele, dan lainnya. Pembuatan produk dilakukan oleh keluarga-keluarga yang diakomodasi oleh kelompok kerja kampung KB Purbonegaran.

Susunan pengurus Kampung KB Purbonegaran melibatkan warga dari kedua RW yang termasuk dalam wilayah administratif Kampung Purbonegaran, yaitu RW 10 dan RW 11. Pengurus Kampung KB Purbonegaran terdiri dari berbagai bidang, salah satunya adalah Seksi Ekonomi yang mengelola kegiatan usaha mikro warga kampung, termasuk kuliner.

Kegiatan usaha di bidang kuliner di Kampung KB Purbonegaran merupakan bagian dari Usaha Peningkatan Pendapatan dan Kesejahteraan (UPPKS) Keluarga yang dikelola oleh Seksi Ekonomi. UPPKS Keluarga di Kampung Purbonegaran mengkoordinasi usaha individu yang di antaranya adalah usaha kuliner, jahit dan laundry.
Usaha kuliner merupakan jenis usaha yang paling banyak dilakukan oleh warga Kampung Purbonegaran, baik pada skala kecil di lingkungan kampung maupun skala besar yang dapat dijangkau secara online. Upaya yang dilakukan oleh UPPKS Keluarga untuk meningkatkan penghasilan warga kampung adalah memasarkan produk kuliner yang dihasilkan oleh warga melalui warung jajan pasar yang beroperasi setiap hari pada jam 5.00 - 10.00 WIB.

Warung pagi yang dikelola oleh UPPKS Keluarga, Kampung KB Purbonegaran berada di atas trotoar yang terletak di seberang Galeria Mall. Warung ini memasarkan jajan pasar dan makanan untuk sarapan pagi yang diproduksi oleh warga Kampung Purbonegaran. Menurut Ibu Sri Lestari sebgai ketua pengelola UPPKS Keluarga, jenis makanan dan jumlahnya sangat tergantung oleh penyetor. Pada awal mula dibukanya warung pagi, banyak penyetor makanan yang berpartisipasi, namun pada perkembangannya hanya sebagian penyetor makanan yang masih bertahan.

Berdasarkan latar belakang tersebut di atas, maka Bapak Hadi Sutarmanto, Ketua LPMK Kelurahan Terban memiliki gagasan untuk melakukan inovasi terhadap usaha kuliner Kampung KB Purbonegaran, supaya lebih berdaya saing dan pada akhirnya dapat meningkatkan penghasilan dari pemasaran produk kulinernya. Oleh karenanya, Kampung KB Purbonegaran mengajukan permohonan pendampingan kepada Tim Pengabdian kepada Masyarakat UKDW sebagai kelanjutan dari program PkM tahun 2020 yang menghasilkan luaran berupa Masterplan Kampung Purbonegaran.

Penurunan kondisi perekonomian warga Kampung Purbonegaran pandemi COVID-19 mendorong warga kampung dan pemerintah Kelurahan Terban untuk berupaya memulihkan kondisi perekonomiannya (Kelurahan Terban, 2021). Salah satu upaya yang dilakukan adalh meningkatkan kualitas produk usaha kuliner yang dikelola oleh Usaha Peningkatan Pendapatan dan Kesejahteraan (UPPKS) Keluarga di bawah koordinasi Kampung KB Purbonegaran. Namun, keterbatasan sumber daya manusia dalam mengembangkan usaha kuliner yang lebih kreatif dan berdaya saing menjadi kendala untuk mewujudkan upaya tersebut. Oleh karenanya, Kampung KB Purbonegaran melakukan kemitraan dengan kampus UKDW, melalui Tim PkM, untuk melakukan pendampingan usaha kuliner kreatif yang dapat meningkatkan pemasaran produk kulinernya. Kendala lain yang dihadapi adalah keterbatasan ruang gerak pada masa pandemi, sehingga upaya pendampingan secara fisik tatap muka pada kelompok usaha mikro di Kampung Purbonegaran ini sangat terbatas.

Usaha Peningkatan Pendapatan dan Kesejahteraan (UPPKS) Keluarga, Kampung KB (Keluarga Berkualitas) Purbonegaran memiliki sarana dan prasarana usaha kuliner 
yang lebih menarik sehingga dapat meningkatkan pemasaran produk kulinernya. Sasaran program Pengabdian kepada Masyarakat ini adalah kelompok masyarakat yang tergabung dalam Usaha Peningkatan Pendapatan dan Kesejahteraan (UPPKS) Keluarga, Kampung KB (Keluarga Berkualitas) yang bergerak di bidang kuliner.

\section{MEtOdE PELAKSANAAN}

Program ini dilaksanakan di Kampung Purbonegaran, Kelurahan Terban, Yogyakarta. Adapun secara lebih spesifik target area yang menjadi kajian adalah wilayah yang berada dalam lingkup RW 10 dan 11. Pelaksanaan kegiatan ini diawali dengan pembuatan masterplan Purbonegaran yang didapatkan dari metode FGD. Proses penyusunan masterplan di Kampung Purbonegaran ini menggunakan metode Forum Group Discussion yang bertujuan untuk melibatkan partisipasi masyarakat setempat. Melalui FGD diharapkan masyarakat setempat aktif dalam menyumbangkan pemikiran-pemikiran untuk mengembangkan lingkungan tempat tinggalnya.

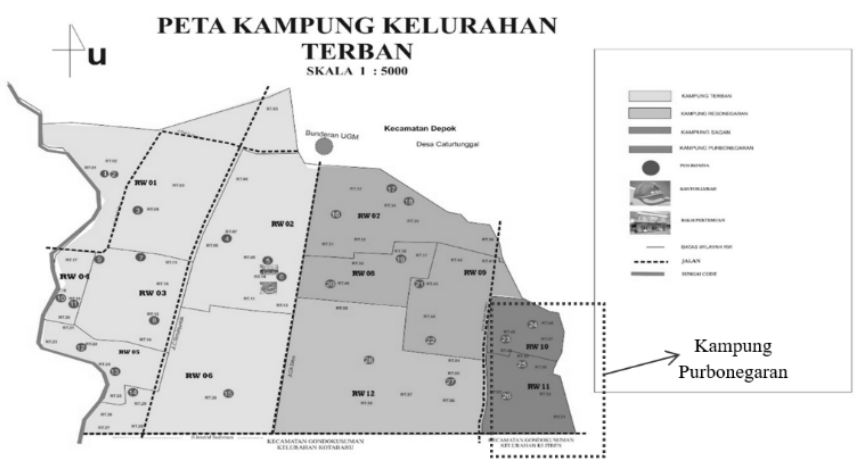

Gambar1. lokasi Kampung Purbonegaran

Setelah Masterplan Purbonegaran selesai dilanjutkana Musrembang Kelurahan Terban. Kegiatan ini digunakan untuk memotivasi kampung yang lain untuk melakukan perencanaan secara terintegrasi. Langkah selanjutnya adalah observasi lapangan dan interview terkait dengan kebutuhan desain yang bertujuan pengembangan ekonomi. Selanjutnya dilanjutkan FGD dan kegiatan workshop.

Peserta yang terlibat dalam kegiatan FGD dan Workshop adalah masyarakat Kampung Purbonegaran dan secara khusus kelompok Kampung KB (Keluarga Berkualitas). FGD merupakan salah satu teknik pengumpulan data kualitatif yang digunakan oleh pembuat keputusan karena lebih mudah untuk memahami sikap, keyakinan dan ekspresi dan istilah yang biasa digunakan oleh peserta (Paramita dan Kristiana, 2013). Workshop dilakukan dalam upaya untuk meningkatkan kualitas lingkungan, sosial, dan ekonomi warga kampung. Workshop merupakan program informal yang memiliki metode pelaksanaan belajar mengajar dan mendorong para peserta untuk aktif (Suprayekti dan Anggraeni, 2017). Kedua metode tersebut menekankan pada proses partisipatif yang dirancang terstruktur antara kebijakan pemerintah dengan kebutuhan warga Kampung Purbonegaran.

Berkaitan dengan masa pandemi, beberapa tahapan kegiatan perlu disesuaikan menggunakan metode daring, ataupun luring dengan penerapan protokol Kesehatan yang ketat dan jumlah peserta yang dibatasi.
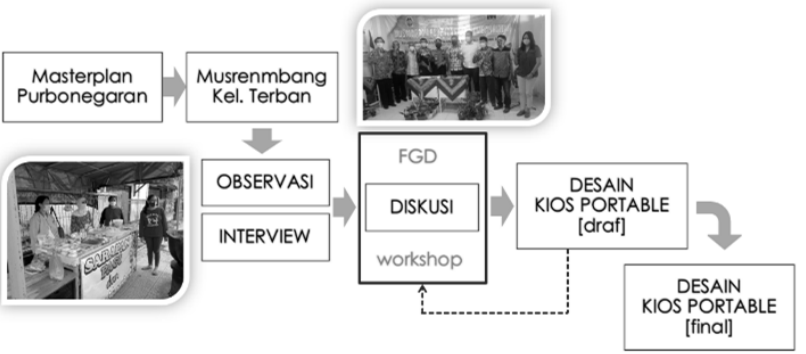

Gambar 2. Metode Pelaksanaan kegiatan PkM Pengembangan Ekonomi Warga Purbonegaran

Setelah terjadi diskusi dengan Pengurus Kampung Purbonegaran dan Pengurus Kelompok KB, maka masuk kedalam tahap desain. Proses diskusi ini membutuhkan waktu yang cukup lama dan berlangsung secara bolak-balik agar mendapatkan desain yang sesuai dengan Kampung Purbonegaran. Di tahap akhir kegiatan ini yaitu finalisasi desain kios portable berupa gambar-gambar teknis kios yang telah diusulkan.

\section{HASIL DAN PEMBAHASAN}

Kegiatan masyarakat Kampung Purbonegaran yang bervariasi menghasilkan banyak potensi yang dapat dikembangkan. Selain potensi, di dalam kampung ini juga terdapat banyak kelemahan yang muncul dalam pengembangan branding kampung. Oleh sebab itu, dalam perencanaan program perlu adanya analisis SWOT untuk memahami kebutuhan dalam pengembangan branding kampung yang sesuai dengan arahan pemerintah dan kondisi yang ada di lokasi. Kampung Purbonegaran memiliki keunikan pada setiap lorong kampung, seperti kebun strawberry vertikal, kebun herbal milik perorangan, rumah-rumah kuno peninggalan masa lalu serta posko kegiatan anak-anak "Belik Kids". Keberadaan fasilitas dan kondisi lasekap kampung Purbonegaran tersebut menjadi potensi yang kuat untuk memperbaiki branding Kampung Purbonegaran.

Adapun potensi yang dimiliki oleh Kampung Purbonegaran adalah sebagai berikut.

1) Letak kampung yang strategis, berada di tengah kota. 
2) Adanya kelompok kewirausahaan kampung yaitu wirausaha lele, kelompok Belik HIPSA (Budaya Eman Lingkungan Idaman Kita Hijau, Indah, Bersih Aman), dan kelompok batik Kampung Purbonegaran

3) Warga yang senang menanam Tanaman Obat Keluarga

4) Adanya perkumpulaan Belik Kids yang menjadi tempat anak-anak belajar

5) Sanggar budaya seni dan karawitan (keroncong Purbanada, keroncong Purbo Rahayu, kelompok tari anak)

6) Bentuk bangunan limasan yang memperlihatkan arsitektur vernacular yang menarik

7) Adanya banyak kelembagaan yang aktif diantaranya PKPM, Panmukti Loyo, YBM (sekolah minggu dan TPA), Panca Tohib (ketertiban), Posyandu untuk remaja, balita, dan lansia, Kampung Tangguh Bencana (KTB), Kampung KB, Pusat Informasi Remaja (PIK.R).

8) Warga yang Sebagian besar merupakan pelaku bisnis seperti jahit, warung makan, toko kelontong, asrama, salon, kos-kosan, clothing, laudry, gas, dan kuliner.

9) Tingkat kerukunan warga yang tinggi dengan adanya kelembagaan dan kegiatan warga yang dilakukan secara periodik.

Potensi-potensi ini menjadi titik awal dalam mengenal kondisi lokal yang menjadi sumber pengembangan ekonomi, social budaya, dan lingkungan.

Identifikasi kelemahan menjadi penting untuk mengingatkan kebutuhan akan program pengembangan. Kelemahan yang dimiliki oleh Kampung Purbonegaran adalah sebagai berikut.

1) Belum ada program-program yang terarah yang mampu mewujudkan branding kampung

2) Belum maksimal dalam penataan fisik kampung yang mampu dijual untuk wisata

3) Bangunan yang memiliki keindahan arsitektur perlu diperhatikan dan diperbaiki

4) Lahan yang terbatas (permukiman padat sedang)

5) Warga sulit mendapatkan modal dan melakukan pemasaran produk yang dihasilkan

6) Warga kurang memiliki motivasi / inisiatif untuk berkembang

7) Jumlah lansia yang tinggi

Kelemahan yang ada lebih banyak terkait program, pemanfaatan lahan, perekonomian, dan kriteria warga. Kelemahan-kelemahan ini bersifat mudah berkembang/dinamis. Oleh sebab itu, peluang untuk merubah kelemahan menjadi kekuatan.

Letak Kampung Purbonegaran yang berada di tengah kota memberikan banyak peluang. Peluang-peluang tersebut antara lain.

1) Kondisi sosial masyarakat yang guyup dan rukun
2) Masyarakat yang memiliki budaya menanam sayur dan tanaman obat keluarga

3) Masyarakat yang memiliki jiwa entrepreneurship

4) Masyarakat yang mau berkembang dan belajar

5) Kampung memiliki modal fisik dan modal sosial yang masih dapat ditingkatkan

6) Munculnya platform online seperti Gojek, Grab, dan Maxim yang dapat membantu usaha warga.

Identifikasi kondisi lokal yang dilakukan melalui FGD belum semuanya dapat memotret kondisi Kampung Purbonegaran. Identifikasi kekuatan dan kelemahan dapat dilakukan dengan mudah oleh peserta FGD, namun berbeda halnya dengan perumusan peluang dan tantangan. Hal ini mencerminkan masih terbatasnya kemampuan warga kampung dalam merefleksikan kondisinya, sehingga perumusan konsep pengembangan kampung juga harus dilakukan secara bertahap. Meski demikian, dapat disebutkan bahwa secara tidak langsung warga Kampung Purbonegaran menyadari bahwa lokasi kampung yang berada di kawasan pusat komersial dapat menjadi peluang sekaligus ancaman bagi Kampung Purbonegaran. Peluang diperoleh melalui fungsi sebagai kawasan penyangga pusat bisnis yang dapat menjadi sumber mata pencaharian bagi warga kampung. Ancaman dapat ditimbulkan oleh kehadiran pendatang yang berpengaruh terhadap menurunnya kualitas interaksi antar warga kampung. 


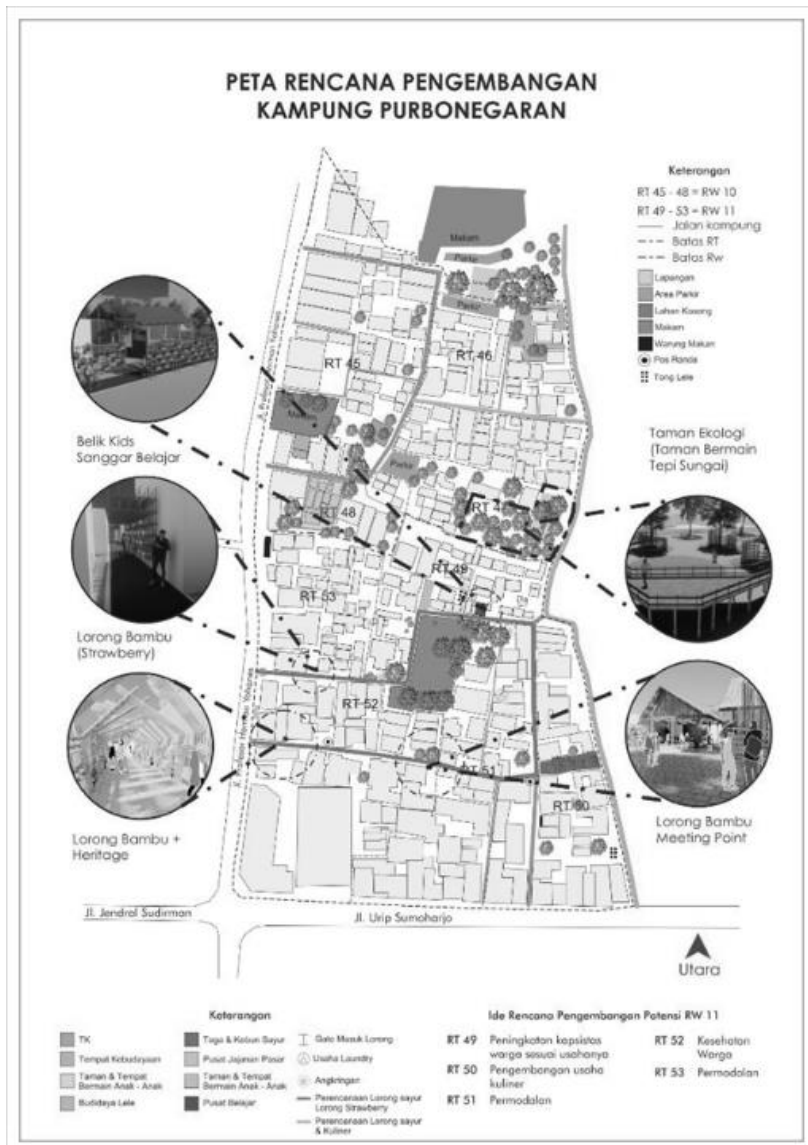

Gambar 3. Masterplan Kampung Purbonegaran, Kelurahan Terban, Kota Yogyakarta [9]

Seperti Masterplan yang dihasilkan oleh program PkM tahun 2020 (Gambar 1) Kampung Purbonegaran akan dikembangkan sesuai dengan branding kampung yang dicanangkan oleh Kelurahan Terban, yaitu sebagai kampung budaya, sayur dan herbal. Branding Kampung Purbonegaran sebagai kampung budaya, sayur dan herbal diperkuat dengan desain lorong kampung dan fasilitas publik yang direncanakan [9] berupa:

- Lorong Bambu Heritage

- Meeting Point di Lorong Bambu Heritage

- Lorong Bambu Strawberry

- Belik Kids Sanggar Belajar

- Taman Ekologi Tepi Sungai

Berdasarkan pada Masterplan Kampung Purbonegaran tersebut, warung pagi merupakan bagian dari Lorong Bambu Heritage. Mengingat keterbatasan sumber daya, maka kondisi sarana prasarana warung pagi tersebut dianggap masih terlihat sederhana dan perlu ditingkatkan kualitas desain secara fisik maupun isi dari warung tersebut.

Dengan potensi kuliner yang dimiliki, saat ini kelompok Kampung KB memiliki kios yang berada di area trotoar sisi Timur dari Mal Galeria. Kios ini menawarkan aneka jajanan pasar yang beroperasi setiap hari mulai pukul 06.00 sampai dengan pukul 10.00. setelah tidak digunakan, kios tersebut akan tutup dan tetap berada pada area tersebut, sehingga menimbulkan citra kota yang kurang baik. Hal ini sudah menjadi rutinitas bagi pemiliki kios, karena dinilai cukup merepotkan jika setiap hari harus membawa kios tersebut ke dalam area kampung. Terlebih pelaku kegiatan pada kios tersebut sebagian besar adalah kaum Wanita. Maka dari itu, diperlukan sebuah inovasi terkait model kios yang digunakan oleh Kelompok kampung KB ini. Tujuannya adalah tetap mempertahankan kegiatan jual beli produk kuliner namun tidak mengorbankan kualitas visual dari Kawasan tersebut.

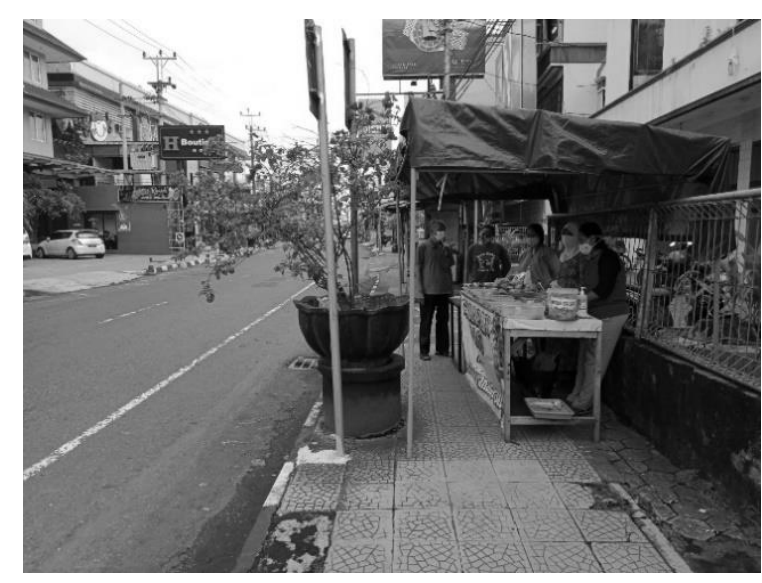

Gambar 4. Kondisi eksisting Kios Kampung KB Purbonegaran

Solusi yang ditawarkan adalah kios portable. Desain kios secara portable ini memungkinkan untuk mudah dipindahkan tanpa perlu usaha yang besar, dan juga mampu melindungi produk dagangan dari polusi kendaraan yang padat melintas di sekitarnya. Terdapat 2 alternatif desain yang diusulkan kepada kelompok Kampung KB Purbonegaran. Kedua desain menerapkan prinsip portable sehingga memungkinkan mobilisasi yang lebih mudah. Selain itu ruang yang digunakan tidak terlalu besar mengingat variasi produk yang diperdagangkan juga relative tidak banyak. Kedua alternatif desain ini menjadi bahan pertimbangan bagi kelompok KB Purbonegaran untuk mengembangkan lokasi usaha kulinernya agar dapat lebih menarik bagi konsumen sekaligus dapat menjaga kualitas lingkungan Kawasan sekitarnya. 

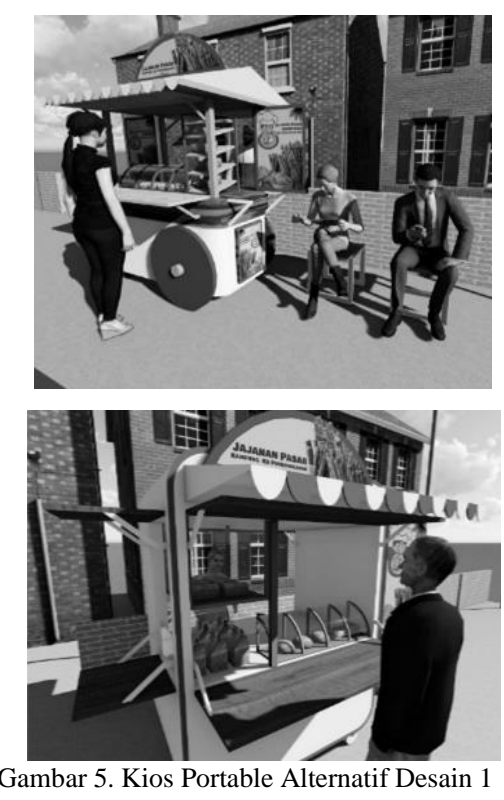

(Sumber: Tim PkM UKDW, 2021)
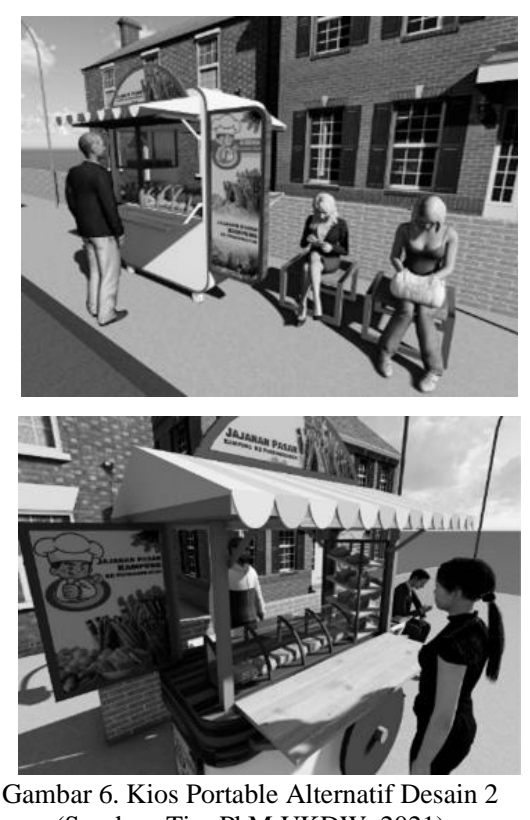

(Sumber: Tim PkM UKDW, 2021)

\section{KESIMPULAN}

Masterplan tata ruang Kampung Purbonegaran berbasis potensi lokal dilanjutkan dengan desain Kios kuliner Kampung KB (Keluarga Berkualitas). Strategi desain kios portable yang atraktif diharapkan dapat menambah daya jual dari anggota Kampung KB dan daya beli masyarakat umum.

Modifikasi metode pelaksanaan PkM akibat situasi pandemi yaitu komunikasi daring dengan pengurus untuk menjaring kebutuhan dan menampung ide-ide pengembangan kios, yang kemudian dilanjutkan dengan pengusulan desain oleh Tim PkM dan feedback dari pengurus Kampung KB.

Sistem pengelolaan kios yang lebih jelas/transparan untuk meningkatkan minat anggota Kampung KB untuk memproduksi makanan atau jajan pasar. Dorongan dari Pengurus Kampung KB Purbonegaran kepada anggotanya untuk memanfaatkan hasil pelatihan sebelumnya. Peningkatan motivasi anggota Kampung KB melalui desain ruang berjualan/kios dan logo produk pengurus Kampung KB Purbonegaran. Kemitraan Gandheng Gendhong signifikan untuk peningkatan perekonomian melalui usaha kuliner.

\section{UCAPAN TERIMA KASIH}

Terimakasih kami sampaikan kepada Lembaga Penelitian dan Pengabdian kepada Masyarakat (LPPM) Universitas Kristen Duta Wacana, atas dukungannya dalam kegiatan pengabdian ini. Kami juga berterimakasih kepada Pengurus Kampung Purbonegaran dan Pengurus Kelompok Keluarga Berkualitas (KB) Kampung Purbonegaran atas kesempatannya dalam melakukan kegiatan pengabdian.

\section{DAFTAR PUSTAKA}

[1] H. Mulyandari, Pengantar Arsitektur Kota, Yogyakarta: Penerbit Andi, 2011.

[2] Suradi, "Pertumbuhan Ekonomi Dan Kesejahteraan Sosial," Informasi, vol. 17 , no. 3, pp. 144-157, 2012.

[3] Humas Kementerian Pendayagunaan Aparatur Negara dan Reformasi Birokrasi. (2020, Agustus 12). Gandeng Gendong Mengentaskan Kemiskinan Kota Yogyakarta. [Online]. Available: https://menpan.go.id/site/berita-terkini/gandeng-gendongmengentaskan-kemiskinan-kota-yogyakarta. [Accessed 10 September 2021].

[4] Eka Putra, Nova Elsyra, Muchamad Zaenuri, "Tata Kelola Kolaborasi Dalam Penanganan Kemiskinan Di Kota Yogyakarta : Program "Gandeng-Gendong"," Jurnal Tata Sejuta STIA MATARAM, vol. 6, no. 2, pp. 571-592, 2020.

[5] M, Robinson Tarigan, Perencanaan Pembangunan Wilayah, Jakarta: PT Bumi Aksara, 2005

[6] Ramadhan, Azka. (2021, April 22). Fase Ketiga Implementasi Gandeng Gendong, Pemkot Yogya Dorong 42 Kelurahan Susun Masterplan. [Online]. Available: https://jogja.tribunnews.com/2021/04/22/fase-ketiga-implementasigandeng-gendong-pemkot-yogya-dorong-42-kelurahan-susunmasterplan?page $=2$. [Accessed 10 September 2021]

[7] Fadli, Rizal (2020, Maret 26). WHO Ubah Social Distancing menjadi Physical Distancing. [Online]. Available:

https://www.halodoc.com/artikel/alasan-who-ubah-social-distancingmenjadi-physical-distancing. [Accessed 10 September 2021].

[8] Badan Kependudukan Dan Keluarga Berencana Nasional. Pedoman bagi Pengelola Kampung KB, Jakarta: Badan Kependudukan Dan Keluarga Berencana Nasional, 2017.

[9] Penetapan Desa/Kelurahan Budaya. Keputusan Gubernur DIY No.262/Kep/216. [Online]. Available: http://jdih.jogjaprov.go.id/storage/1486705895skgub262-2016.pdf. [Accessed 31 Oktober 2021]. 
[10] Wiyatiningsih; Patricia Pahlevi Noviandri; Christian Nindyaputra Octarino, "Penguatan Branding Kampung Purbonegaran melalui Penataan Kampung dan Potensi Kuliner," unpublished. 